Bangladesh J. Bot. 49(3): 521-530, 2020 (September)

\title{
GENETIC VARIABILITY AMONG SEEDLING ORIGIN TREE POPULATION OF MANGO (MANGIFERA SPP.) IN HIMACHAL PRADESH, INDIA
}

\author{
Mahesh G Bhoyar and Krishan Kumar \\ Department of Fruit Science, Dr. Yashwant Singh \\ Parmar University of Horticulture and Forestry, Nauni-Solan, Himachal Pradesh, 173230
}

Keywords: Mangifera species, Seedling origin, Genetic variability, Breeding program, Fruit characters development

\begin{abstract}
A survey to the existing seedling origin tree population of wild Mangifera spp. was carried out at Hamirpur and Kangra districts of Himachal Pradesh, India. Eighty one healthy and bearing tree population originated from seedlings in the region were marked. Wide range of genetic variability in qualitative and quantitative characters were observed for fruit, stone, peel, pulp and other fruit characters. Hamirpur district exhibited a variety in quality of fruits with varied fruit shape, colour, attractiveness etc. The significant variation was observed for different fruit parameters like fruit dimensions, fruit weight, fruit volume, stone weight, stone length, of stone, stone thickness, of stone, pulp weight, peel weight, per cent of edible and nonedible portions, ratio of stone weight to pulp weight, ratio of peel weight to pulp weight, skin thickness and TSS (Total Soluble Solids). The selected genotypes could be classified into different categories based upon their utility, viz., pickle, sucking, table purposes etc.
\end{abstract}

\section{Introduction}

The mango is undoubtedly the most important fruit crop of India. It covers largest area compared to any other fruit in the country and thrives in almost all regions except at altitudes above 3000 feet and prefers frost-free dry climates (Gangolly et al. 1957). Mango has a long period of domestication in India resulting in high genetic variability. The majority of the commercial varieties of mango in India have originated as natural chance selections (Dey and Singh 2004). Mango being a highly cross-pollinated and heterozygous fruit crop exhibits wide genetic variability in seedling population. Majority of cultivated mango varieties were developed through selection on the basis of fruit shape, size, colour, time of maturity, juice, content, TSS/acid blend, flavour, aroma, taste, etc. Presently, India harbours more than 1000 mango varieties/land races in regions of different diversity and represents the biggest mango genepool of the world. In sub-mountane zone of Himalayan region, old mango plantation predominantly from seedling origin are established naturally or propagated through selected stones from meritorious indigenous mango plants on the basis of fruit quality characteristics by local fruit lover during 19th and early 20th century. These are at present mostly growing along a strip of roads, riverbanks, undulated terrain in mountainous tracts, government revenue lands, mango groves, etc., exhibit a wide range of variability in desirable horticultural traits like fruit shape, size, juice consistency, bearing regularity, fruit yield, tolerance/resistance to various biotic and abiotic stresses (Navprem et al. 2011). Keeping this insight variation in seedling tree population of mango was explored to assess their possibilities in future fruit crop improvement program.

\section{Materials and Methods}

Mango, having an andromonoecious floral structures encourages cross pollination. This enables a greater diversity within. Mango harbours more than 1000 registered varieties but potential of seedling origin trees is still unknown. As each seedling origin mango exhibits a unique

\footnotetext{
*Author for correspondence: <mahesh.bhoyar@gmail.com>.
} 
feature the survey was undertaken to explore the existing variability in mango of seedling tree origin in Himachal Pradesh for utilization its potential in future breeding programs. The study was conducted covering entire seedling mango tree population existed in Hamirpur and Kangra districts of Himachal Pradesh, India. It was carried out on existing seedling tree population of mango, during 2013 - 15. The region opted for research particularly falls under sub-mountain zone which stretched from $\mathrm{N} 31^{\circ} 30^{\prime}$ to $\mathrm{N} 32^{\circ} 15^{\prime}$ and $\mathrm{E} 75^{\circ} 45$ to $76^{\circ} 35^{\prime}$ with elevation ranging from $551-2550 \mathrm{~m}$. covering a ground distance of about $567 \mathrm{~km}$ which conceals entire seedling mango tree population existed. Out of total population 81 healthy and bearing seedling mango trees were subjected for selection. Fruits from each marked tree were subjected for detailed morphophysicochemical evaluation. A total of 20 fruits were selected randomly from all directions from each individual tree and used for evaluation. The traits considered for evaluation were fruit dimension, fruit weight, fruit volume, stone weight, pulp weight, peel weight, stone/pulp ratio, edible and non-edible portion per cent, fruit shape, skin color, fruit blush, skin thickness, skin texture, pulp texture, adherence of skin to pulp, fiber content, beak type, sinus type and slope of shoulders. The morphological characterization was done adopting standard mango descriptors developed by the IPGRI (IPGRI 2006). The chemical analysis conducted by following standard protocols.

\section{Results and Discussion}

The fruit characters are almost exclusively reliable for identification, description and classification of mango varieties and germplasm. Visual characters like fruit shape, peel color etc. could be considered as basic indicative tools in identification of germplasm (Naik and Gangolly 1950, Singh and Singh 1956). Cumulative length and breadth of fruits ranged from 13.98 (MkH1) to $80.58 \mathrm{~cm}^{2}(\mathrm{HmH} 3)$ with an average dimension of $28.24 \mathrm{~cm}^{2}$. Coefficient of variation was recorded as 38.59 per cent. Average fruit weight among sampled fruits was 60.62 gram. There existed a wide variation in terms of fruit morphological characters. Mean weight of fruit ranged from 27.55 (MkH6) to $169.12 \mathrm{~g}$ (KgH1). Coefficient of variation was recorded as 47.57 per cent. Volume of fruit measured among sampled tree population revealed that average fruit volume was $65.57 \mathrm{ml}$ which ranged from $31.50 \mathrm{ml}$ (MkH1) to $178.83 \mathrm{ml}$ (HmH3). Coefficient of variation was recorded as 43.32 per cent. Growth is an irreversible increase in fruit dimensions, fruit weight and volume of the fruit. Due to cell division (increase in number) and cell enlargement (increase in size) fruit weight increases day by day. Fresh weight is less useful because it fluctuates, depending on the moisture status of the fruit. The variation in fruit morphological characters of the different seedling mango trees noticed may be due to genetic or physiological factors. These observations are in agreement with the findings of Iyer et al. (1988), Haque et al. (1993), Chaudhari et al. (1997), Desai and Dhander (2000), Anila and Radha (2003), Kumar and Bramhachari (2004), Kundu et al. (2013). The studies at various locations across the globe on fruit morphological characters of mango concluded a common phenomenon that genetic or physiological factors govern this wide existing variation among them (Table 1 and Chart 1). Weight of stone ranged between 6.34 (MkH6) and $40.31 \mathrm{~g}(\mathrm{KgH} 1)$. The average weight of stone was $14.43 \mathrm{~g}$ with 46.59 per cent coefficient of variation. Length of stone varied from $17.78 \mathrm{~mm}$ (UpH5) to $71.47 \mathrm{~mm}$ (SiH2). Average length of stone was $35.78 \mathrm{~mm}$ with 35.77 per cent coefficient of variation. Width of stone ranged between $10.95(\mathrm{MkH} 1)$ and $51.28 \mathrm{~mm}(\mathrm{SiH} 2)$. The average width of stone was $24.17 \mathrm{~mm}$ with 36.79 per cent coefficient of variation. Thickness of stone varied from 14.83 (UpH5) to $37.26 \mathrm{~mm}(\mathrm{HmH} 3)$ with an average of 21.31. Coefficient of variation was recorded as 18.90 per cent. Though shape of fruit is considered as a diagnostic character for description and identification of mango fruit, but stone characters could be taken up as secondary character in classification of mango (Singh and Singh 1956). There exist numerous 


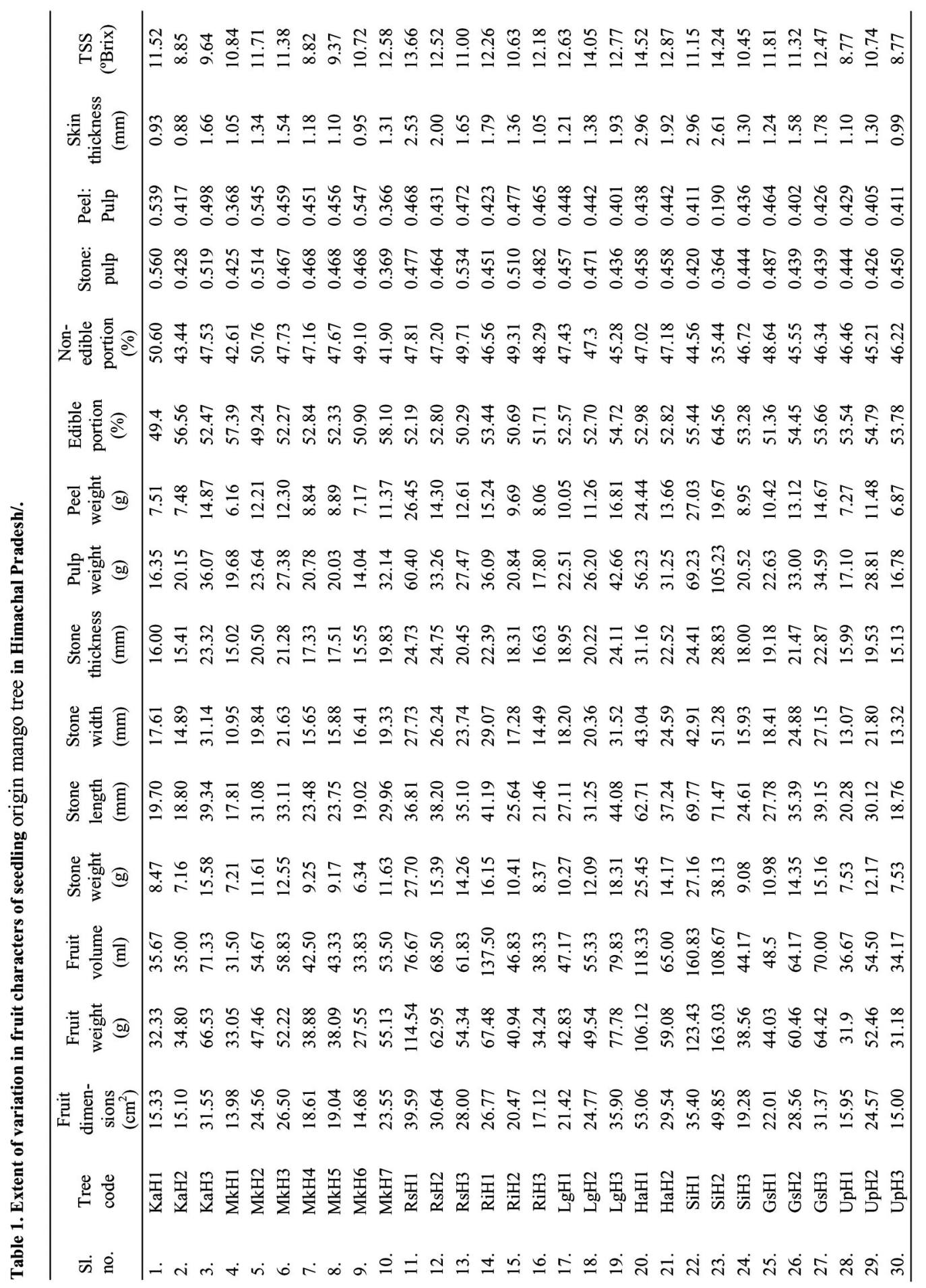




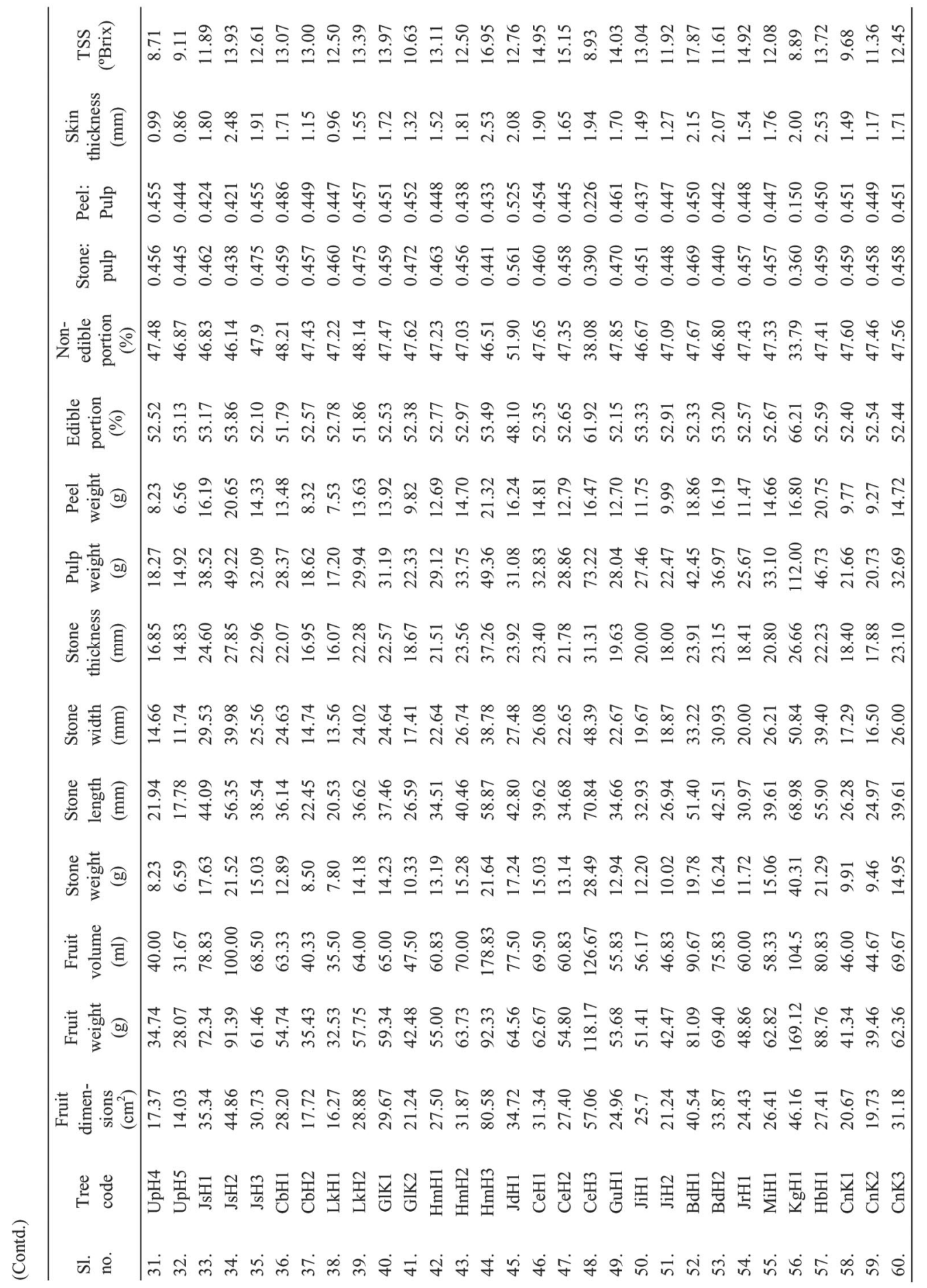




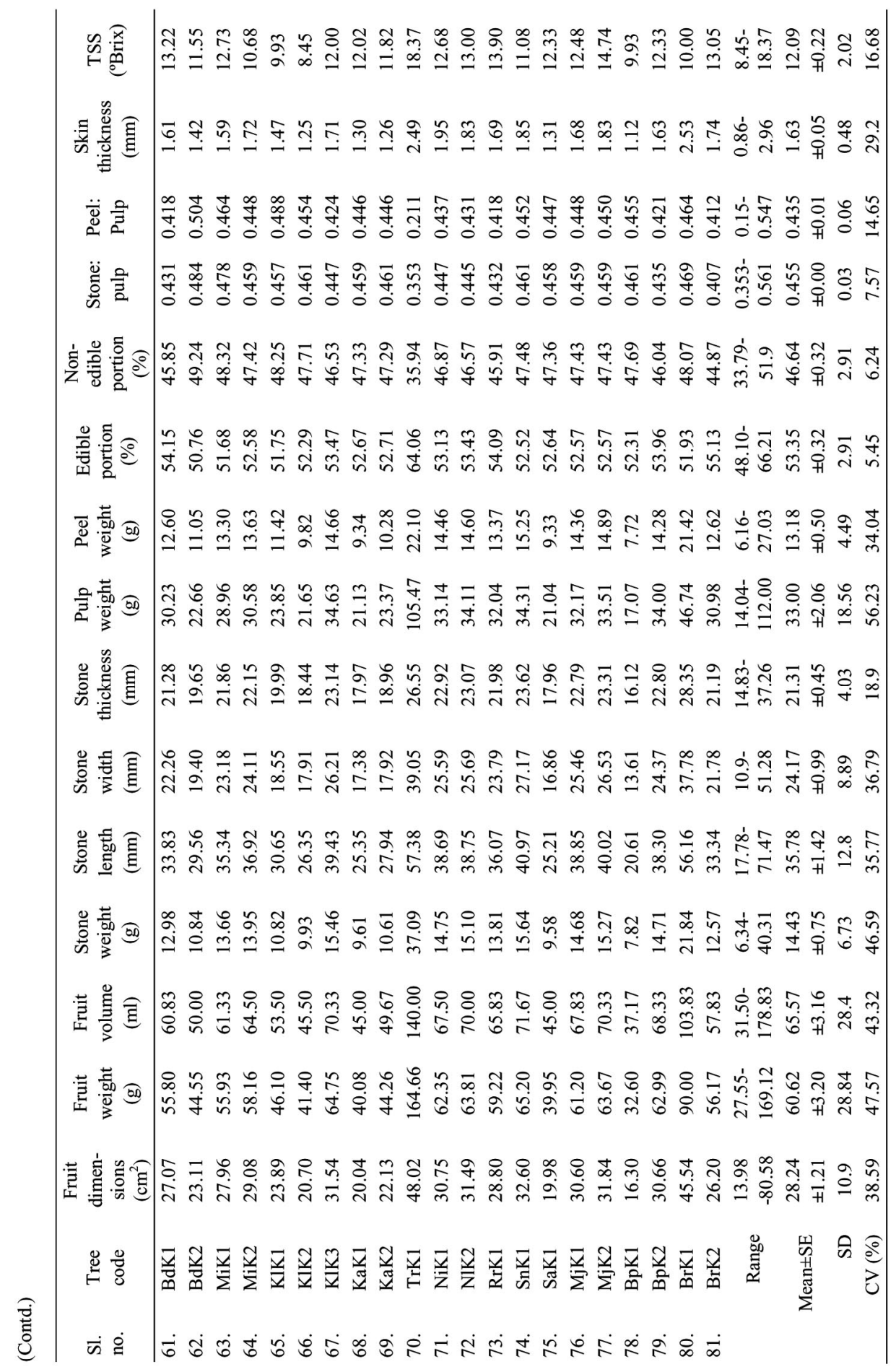




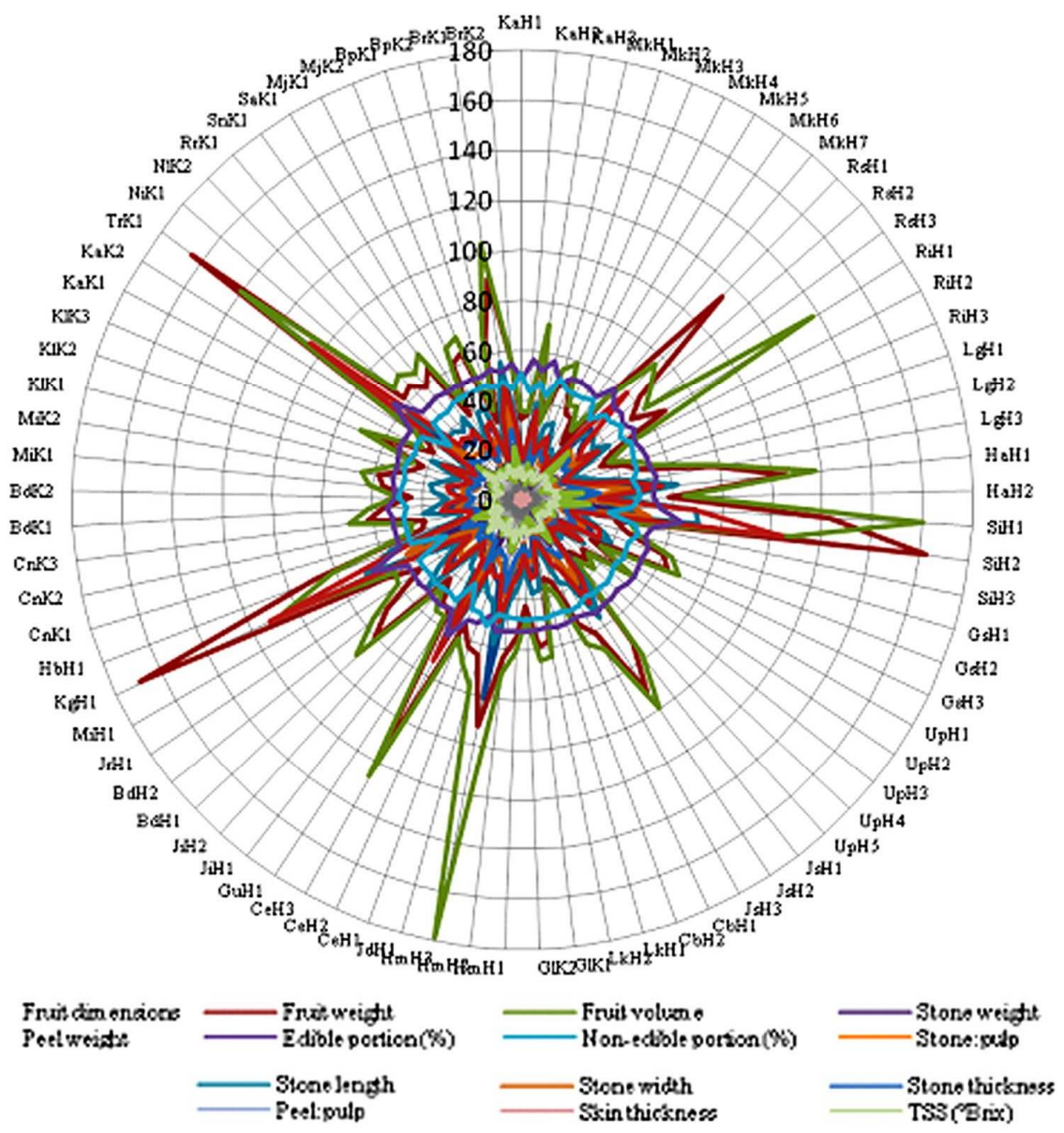

Chart 1. Extent of variation in fruit characters of seedling origin mango tree in Himachal Pradesh.

mango cultivars in different agro-climatic conditions across the Indian sub-continent. These are mostly similar but having different names to avoid confusion a careful classification based upon additional taxonomical characters like stone characters needed to be supplemented with present distinguishing characters (Teaotia 1971, Singh and Bana 1976). Further, it is a prerequisite for fruit breeders to design a breeding program considering viable strategy which boosts commercial utility of mango fruit. Thus, stone characters are very much vital for commercial exploitation in mango processing industries (Sadhu and Bose 1982) (Table 1 and Chart 1). Pulp weight ranged from 14.04 (MkH6) to $112.00 \mathrm{~g} \mathrm{(KgH1)} \mathrm{with} \mathrm{an} \mathrm{average} \mathrm{of} 33.00 \mathrm{~g}$. The coefficient of variation was recorded as 56.23 per cent. Peel weight ranged from $6.16(\mathrm{MkH} 1)$ to $27.03 \mathrm{~g}(\mathrm{SiH} 1)$ with an average of $13.18 \mathrm{~g}$. The coefficient of variation was recorded as $34.04 \%$. Per cent edible portion in sampled mango fruit varied from $48.10(\mathrm{JdH} 1)$ to $66.21(\mathrm{KgH} 1)$ with an average of 53.35. The coefficient of variation was recorded as $5.45 \%$. Per cent non-edible portion sampled mango fruit ranged between $33.79(\mathrm{KgH} 1)$ and $51.9(\mathrm{JdH} 1)$ with an average of 53.35. The coefficient of variation was recorded as $6.24 \%$. Ratio of weight of stone to weight of pulp varied from 0.353 (TrK1) to $0.561(\mathrm{JdH} 1)$ with an average of 0.455 . Coefficient of variation was recorded as 
Table 2. Extent of variation in yield characters of seedling origin mango tree in Himachal Pradesh.

\begin{tabular}{|c|c|c|c|c|c|}
\hline \multirow[b]{2}{*}{$\begin{array}{l}\text { Sl. } \\
\text { No. }\end{array}$} & \multirow[b]{2}{*}{$\begin{array}{l}\text { Tree } \\
\text { code }\end{array}$} & \multicolumn{2}{|c|}{ On year } & \multicolumn{2}{|c|}{ Off year } \\
\hline & & $\begin{array}{c}\text { Yield } \\
(\mathrm{kg} / \text { tree })\end{array}$ & $\begin{array}{l}\text { Yield efficiency } \\
\left(\mathrm{kg} / \mathrm{cm}^{2}\right)\end{array}$ & $\begin{array}{c}\text { Yield } \\
(\mathrm{kg} / \text { tree })\end{array}$ & $\begin{array}{l}\text { Yield efficiency } \\
\left(\mathrm{kg} / \mathrm{cm}^{2}\right)\end{array}$ \\
\hline 1. & KaH1 & 65.20 & 0.0169 & 5.10 & 0.0013 \\
\hline 2. & $\mathrm{KaH} 2$ & 61.40 & 0.0238 & 3.50 & 0.0014 \\
\hline 3. & $\mathrm{KaH} 3$ & 50.70 & 0.0176 & 1.60 & 0.0006 \\
\hline 4. & MkH1 & 109.30 & 0.0175 & 2.30 & 0.0004 \\
\hline 5. & $\mathrm{MkH} 2$ & 60.20 & 0.0262 & 4.10 & 0.0018 \\
\hline 6. & $\mathrm{MkH} 3$ & 70.60 & 0.0077 & 0.50 & 0.0001 \\
\hline 7. & MkH4 & 200.20 & 0.0174 & 20.65 & 0.0018 \\
\hline 8. & MkH5 & 90.30 & 0.0118 & 7.36 & 0.0010 \\
\hline 9. & MkH6 & 260.60 & 0.0253 & 21.41 & 0.0021 \\
\hline 10. & MkH7 & 84.30 & 0.0103 & 7.40 & 0.0009 \\
\hline 11. & RsH1 & 193.70 & 0.0168 & 4.10 & 0.0004 \\
\hline 12. & $\mathrm{RsH} 2$ & 45.40 & 0.0129 & 2.90 & 0.0008 \\
\hline 13. & $\mathrm{RsH} 3$ & 60.20 & 0.0625 & 1.76 & 0.0018 \\
\hline 14. & RiH1 & 109.30 & 0.0260 & 1.25 & 0.0003 \\
\hline 15. & $\mathrm{RiH} 2$ & 91.80 & 0.0158 & 3.10 & 0.0005 \\
\hline 16. & RiH3 & 99.10 & 0.0148 & 5.80 & 0.0009 \\
\hline 17. & LgH1 & 30.30 & 0.0470 & 0.00 & 0.0000 \\
\hline 18. & $\mathrm{LgH} 2$ & 57.40 & 0.0427 & 5.20 & 0.0039 \\
\hline 19. & $\mathrm{LgH} 3$ & 42.50 & 0.0441 & 2.50 & 0.0026 \\
\hline 20. & HaH1 & 80.70 & 0.0176 & 8.10 & 0.0018 \\
\hline 21. & $\mathrm{HaH} 2$ & 244.60 & 0.0392 & 21.20 & 0.0034 \\
\hline 22. & $\mathrm{SiH} 1$ & 223.10 & 0.0194 & 20.50 & 0.0018 \\
\hline 23. & $\mathrm{SiH} 2$ & 168.40 & 0.0480 & 4.60 & 0.0013 \\
\hline 24. & $\mathrm{SiH} 3$ & 83.10 & 0.0322 & 3.10 & 0.0012 \\
\hline 25. & GsH1 & 260.20 & 0.0226 & 20.20 & 0.0018 \\
\hline 26. & GsH2 & 146.40 & 0.0417 & 6.41 & 0.0018 \\
\hline 27. & GsH3 & 157.20 & 0.0292 & 7.20 & 0.0013 \\
\hline 28. & UpH1 & 326.50 & 0.0284 & 5.60 & 0.0005 \\
\hline 29. & $\mathrm{UpH} 2$ & 197.80 & 0.0341 & 8.20 & 0.0014 \\
\hline 30. & UpH3 & 218.30 & 0.0326 & 6.43 & 0.0010 \\
\hline 31. & $\mathrm{UpH} 4$ & 120.90 & 0.0344 & 9.30 & 0.0026 \\
\hline 32. & UpH5 & 246.70 & 0.0322 & 7.60 & 0.0010 \\
\hline 33. & JsH1 & 322.50 & 0.0266 & 5.32 & 0.0004 \\
\hline 34. & JsH2 & 305.30 & 0.0266 & 20.10 & 0.0017 \\
\hline 35. & JsH3 & 266.10 & 0.0289 & 6.34 & 0.0007 \\
\hline 36. & $\mathrm{CbH} 1$ & 287.60 & 0.0312 & 6.70 & 0.0007 \\
\hline 37. & $\mathrm{CbH} 2$ & 348.70 & 0.0303 & 7.80 & 0.0007 \\
\hline 38. & LkH1 & 46.50 & 0.0346 & 5.60 & 0.0042 \\
\hline 39. & $\mathrm{LkH} 2$ & 77.60 & 0.0337 & 6.20 & 0.0027 \\
\hline 40. & GlK1 & 49.80 & 0.0370 & 1.30 & 0.0010 \\
\hline 41. & GlK2 & 29.10 & 0.0162 & 0.00 & 0.0000 \\
\hline 42. & HmH1 & 41.60 & 0.0363 & 4.90 & 0.0043 \\
\hline 43. & $\mathrm{HmH} 2$ & 34.30 & 0.0532 & 3.10 & 0.0048 \\
\hline
\end{tabular}


(Contd.)

\begin{tabular}{|c|c|c|c|c|c|}
\hline \multirow[b]{2}{*}{$\begin{array}{l}\text { Sl. } \\
\text { no. }\end{array}$} & \multirow{2}{*}{$\begin{array}{l}\text { Tree } \\
\text { code }\end{array}$} & \multicolumn{2}{|c|}{ On year } & \multicolumn{2}{|c|}{ Off year } \\
\hline & & $\begin{array}{l}\text { Yield } \\
\text { (kg/tree) }\end{array}$ & $\begin{array}{l}\text { Yield efficiency } \\
\left(\mathrm{kg} / \mathrm{cm}^{2}\right)\end{array}$ & $\begin{array}{l}\text { Yield } \\
(\mathrm{kg} / \text { tree })\end{array}$ & $\begin{array}{l}\text { Yield efficiency } \\
\left(\mathrm{kg} / \mathrm{cm}^{2}\right)\end{array}$ \\
\hline 44. & $\mathrm{HmH} 3$ & 28.90 & 0.0567 & 9.40 & 0.0184 \\
\hline 45. & JdH1 & 83.10 & 0.0216 & 0.00 & 0.0000 \\
\hline 46. & $\mathrm{CeH} 1$ & 310.40 & 0.0270 & 4.21 & 0.0004 \\
\hline 47. & $\mathrm{CeH} 2$ & 267.10 & 0.0274 & 11.40 & 0.0012 \\
\hline 48. & $\mathrm{CeH} 3$ & 230.10 & 0.0301 & 10.20 & 0.0013 \\
\hline 49. & GuH1 & 68.30 & 0.2030 & 0.00 & 0.0000 \\
\hline 50. & JiH1 & 78.20 & 0.0303 & 2.98 & 0.0012 \\
\hline 51. & $\mathrm{JiH} 2$ & 108.70 & 0.0258 & 6.92 & 0.0016 \\
\hline 52. & BdH1 & 14.10 & 0.0105 & 0.00 & 0.0000 \\
\hline 53. & $\mathrm{BdH} 2$ & 43.60 & 0.0169 & 1.20 & 0.0005 \\
\hline 54. & JrH1 & 149.80 & 0.1307 & 7.65 & 0.0067 \\
\hline 55. & MiH1 & 19.40 & 0.0144 & 0.50 & 0.0004 \\
\hline 56. & $\mathrm{KgH} 1$ & 96.50 & 0.0166 & 0.00 & 0.0000 \\
\hline 57. & $\mathrm{HbH} 1$ & 34.60 & 0.0679 & 1.87 & 0.0037 \\
\hline 58. & CnK1 & 47.80 & 0.0355 & 0.68 & 0.0005 \\
\hline 59. & CnK2 & 31.60 & 0.0110 & 0.27 & 0.0001 \\
\hline 60. & CnK3 & 25.30 & 0.0188 & 0.43 & 0.0003 \\
\hline 61. & BdK1 & 50.70 & 0.0176 & 2.76 & 0.0010 \\
\hline 62. & $\mathrm{BdK} 2$ & 40.50 & 0.0628 & 3.19 & 0.0049 \\
\hline 63. & MiK1 & 231.70 & 0.0202 & 7.31 & 0.0006 \\
\hline 64. & MiK2 & 238.90 & 0.0178 & 8.91 & 0.0007 \\
\hline 65. & KlK1 & 30.50 & 0.0473 & 0.61 & 0.0009 \\
\hline 66. & $\mathrm{~K} 1 \mathrm{~K} 2$ & 26.50 & 0.0411 & 0.94 & 0.0015 \\
\hline 67. & KlK3 & 27.40 & 0.0538 & 0.00 & 0.0000 \\
\hline 68. & KaK1 & 31.20 & 0.0232 & 0.00 & 0.0000 \\
\hline 69. & $\mathrm{KaK} 2$ & 43.10 & 0.0320 & 0.00 & 0.0000 \\
\hline 70. & TrK1 & 374.30 & 0.0280 & 3.87 & 0.0003 \\
\hline 71. & NiK1 & 14.80 & 0.0186 & 0.00 & 0.0000 \\
\hline 72. & $\mathrm{~N} 1 \mathrm{~K} 2$ & 5.40 & 0.0056 & 0.00 & 0.0000 \\
\hline 73. & RrK1 & 12.60 & 0.0195 & 0.00 & 0.0000 \\
\hline 74. & SnK1 & 43.80 & 0.0382 & 2.78 & 0.0024 \\
\hline 75. & SaK1 & 38.60 & 0.0168 & 5.94 & 0.0026 \\
\hline 76. & MjK1 & 57.20 & 0.0163 & 2.93 & 0.0008 \\
\hline 77. & $\mathrm{MjK} 2$ & 39.60 & 0.0154 & 0.00 & 0.0000 \\
\hline 78. & BpK1 & 63.70 & 0.0473 & 1.48 & 0.0011 \\
\hline 79. & BpK2 & 50.10 & 0.0777 & 2.10 & 0.0033 \\
\hline 80. & BrK1 & 106.40 & 0.0412 & 3.76 & 0.0015 \\
\hline 81. & BrK2 & 40.70 & 0.0227 & 6.95 & 0.0039 \\
\hline Ran & & $5.4-374.3$ & $0.0056-0.203$ & $0.0-21.41$ & $0.0-0.0184$ \\
\hline Mea & $\mathrm{SE}$ & $114.45 \pm 10.91$ & $0.03 \pm 0.0029$ & $5.03 \pm 0.59$ & $0.0015 \pm 0.0002$ \\
\hline SD & & 98.25 & 0.026 & 5.35 & 0.002 \\
\hline $\mathrm{CV}$ & & 85.85 & 81.77 & 106.46 & 149.43 \\
\hline
\end{tabular}


7.57\%. Ratio of peel weight to pulp weight varied from 0.15 (KgH1) to 0.547 (MkH6) with an average of 0.435 . Coefficient of variation was recorded as $14.65 \%$. Pulp weight and per cent of edible portion are important characters from economic point of view. Thickness of skin ranged from $0.86(\mathrm{UpH} 5)$ to $2.96 \mathrm{~mm}(\mathrm{HaH} 1$ and $\mathrm{SiH} 1)$ with an average of $1.63 \mathrm{~mm}$. Coefficient of variation was recorded as $29.20 \%$. There exists considerable variations in pulp and peel weight. But, when it comes to edible and non-edible portion percentage; also, stone to pulp ratio the distinctness among these characters is very low. From processing point of view mango should be pulpier having thinner skin and smaller stone. Lower pulp : stone in fruits makes it suitable for pickling industries (Nalini and Chimmad 2005). Depending upon the objectives of breeding program selection of donor parent should be carefully done. These results are in accordance with the results reported by Gangolly et al. (1957), Lodh et al. (1974), Rabbani and Singh (1988), Mannan et al. (2003). TSS (Total soluble solids) varied between 8.45 (KIK2) and $18.37^{\circ}$ Brix (TrK1) with an average of $12.09{ }^{\circ}$ Brix. Coefficient of variation was recorded as 16.68. TSS content of a solution is determined by the index of refraction. It is widely used during fruit processing to determine the concentration of sugar in the products. During the development of the flesh of a fruit, in many species, nutrients are deposited as starch, which during the ripening process is transformed into sugars. The progression of the ripening process leads to increase in sugar levels. Sweetness of the pulp is the most essential criterion for table or sucking purpose of seedling mangoes. TSS is highly heritable so, strains possessing higher TSS can be directly selected as donor parent or utilized as parent in hybridization program. The consumptive use of mangoes like table, processing, sucking, etc. demands specific type of mango, lower TSS mostly preferred for processing while higher TSS preferred for table/sucking purposes (Das et al. 2007, Sunagar et al. 2015) (Table 1 and Chart 1). During 'on' year i.e. in 2014 sampled seedling mango trees flowered profusely ensuing in decent fruit harvest. The variation in terms of yield observed ranged from 5.40 (NIK2) to $374.30 \mathrm{~kg} / \mathrm{plant}$ ( $\mathrm{TrK} 1$ ) with an average of $114.45 \mathrm{~kg}$ fruits per plant. The coefficient of variation was $85.85 \%$. There was exponential decrease in yield of fruits per plant. Many sampled trees failed to bear fruits but some of them managed to secure a little bit of it. The fruit yield in kg per plant varied between 0.00 and 21.41 (MkH6) with an average of $5.03 \mathrm{~kg}$ fruits per plant. The coefficient of variation was $106.46 \%$ (Table 2). The potential to yield in mango seems to be affected by additive gene which could be influenced by environmental factors. During 'on' year i.e. in 2014 yield potential ranged between $0.0056 \mathrm{~kg} / \mathrm{cm}^{2}$ (NIK2) and 0.203 (TrK1) with an average of $0.03 \mathrm{~kg} / \mathrm{cm}^{2}$. The coefficient of variation was $81.77 \%$. In 'off' year i.e. 2015 observed data revealed wide range of variations in yield potential. There were many sampled trees which failed to bear fruit. The range of variation observed was 0.00 to $0.184 \mathrm{~kg} / \mathrm{cm}^{2}(\mathrm{HmH} 3)$ with an average of $0.0015 \mathrm{~kg} / \mathrm{cm}^{2}$. The coefficient of variation observed was $149.43 \%$. The existing mango tree population originated from seedlings not only adds to biological diversity but can also be utilized in different mango breeding programs for development of superior varieties.

\section{References}

Anila R and Radha T 2003. Physicochemical analysis of mango varieties under Kerala conditions. Journal of Tropical Agriculture 41: 20-22.

Chaudhari SMB, Patil T and Desai UT 1997. Performance of South Indian mango varieties under semi-arid region of Maharashtra. Journal Maharashtra Agriculture University 22: 72-74.

Das BK, Ray DP and Acharya GC 2007. Genetic variability in mango germplasm of Orissa. Indian Journal of Horticulture 64(1): 29-33.

Dash RC and Hota BN 1997. Some indigenous mango varieties of Orissa. Orissa Journal of Horticulture. 5 : $35-52$. 
Desai AR and Dhandar DG 2000. Variation in physico-chemical and morphogenetic characters of some mango varieties of Goa. Acta Horticulturae 509: 243-249.

Dey S and Singh MP 2004. Biological approaches for conservation of plantation crops. In: Bioresources and Genepool Conservation, Daya Publishing House, Delhi, p. 235-237.

Gangolly SR, Singh R, Katyal SL and Singh D 1957. The Mango. Indian Council of Agricultural Research, New Delhi. pp. 1-4.

Haque AMMM, Ali MR, Uddin MR, Hossain AKMA 1993. Evaluation of elite mango cultivars at southern region of Bangladesh. Journal of Plant Breeding Genetics 6: 21-28.

IPGRI 2006. Descriptors for mango (Mangifera indica L). International Plant Genetic Resources Institute, Rome. 1-71.

Iyer CPA, Subbaiah MC, Subramanyam MD and Rao GSP 1988. Screening of germplasm and correlation among certain characters in mango. Acta Horticulturae 231: 83-120.

Kumar N and Bramchari VS 2004. Stone description of some mango varieties at Sabour Bihar. Progressive Horticulture 36(1): 99-102.

Kundu S, Sanyal N, Mazumdar D, Datta P and Ghosh B 2013. Characterization and evaluation of some superior lesser-known cultivars of mango. Acta Horticulturae 975: 81-87.

Lodh SB, Subramanayam MD and Divakar NG 1974. Physico-chemical studies of some important mango varieties. Indian Journal of Horticulture 31(2): 160-162.

Mannan MA, Khan SAKU, Islam MR, Islam MS, Siddiqa A 2003. A study on the physico-chemical characteristics of some mango varieties in Khulna region. Pakistan J. Biol. Sci. 6(24): 2034-2039.

Naik KC and Gangolly SR. 1950. Classification and nomenclature of South Indian mangoes. The Madras Department of Agriculture Printing Press, Madras, India.

Nalini AS and Chimmad BV 2005. Morphological and nutritional diversity of wild mango fruits in Westernghats of Uttar Kannada district. Karnataka Journal Agricultural Sciences 18(2): 320-324.

Navprem S, Jerath N and Singh G 2011. In situ conservation of seedling mango biodiversity in sub mountane region of Punjab. In: Proceedings of International Conference on Preparing Agriculture for Climate Change. (Eds. SK Sandhu, D Pathak, N Sidhu, R Bhardwaj and A Rang). Ludhiana, India. 38: 89-90.

Rabbani A and Singh IS 1988. Evaluation of local sucking mango varieties for beverage industries. Acta Horticulturae 231:715-720.

Sadhu MK and Bose TK 1982. Studies on physico-chemical studies of some promising cultivars of the district Murshidabad, West Bengal. Indian Agriculture 26(4): 243-253.

Singh LB and Singh RN. 1956. A monograph on the mangoes of Uttar Pradesh. Superintendent, Printing and Stationary, U.P., India.

Singh RD and Bana DS 1976. Studies on mango (Mangifera indica L.). Morphological and physico-chemical studies of some important varieties. Indian Journal of Agricultural Sciences 10(3): 159-164.

Sunagar M, Vasudeva R, Sthapit BR, Parthasarathy VA, Reddy BMC and Rao VR 2015. Morphological characterization of a few farmers'-identified unique aromatic pickle mango varieties of the central Western ghats. Indian Journal of Plant Genetic Resources 28(1): 117-122.

Teaotia SS 1971. Studies on mango varieties. II. Morphological and physico-chemical studies of some important table varieties. Punjab Journal of Horticulture 11(3-4): 240-245.

(Manuscript received on 11 April, 2019; revised on 25 July, 2019) 